\title{
PERTANGgUNGJAWABAN KORPORASI TERHADAP PENERAPAN PRINSIP STRICT LIABILITY DALAM KASUS KERUSAKAN LINGKUNGAN HIDUP
}

\author{
Septya Sri Rezeki $\mid$ Br. Pabean Sangsit Sawan Buleleng, \\ septyasrirezeki@ymail.com $\quad$ Singaraja-Bali
}

\begin{abstract}
In the concept of criminal law, criminal liability is meant to determine whether a suspect/defendant should be sentenced for a crime he did or not. In other words whether the accused will be convicted or acquitted. This capability demonstrates a deliberate and negligence error of the defendent. However, Law No. 32 Year 2009 regulates the corporate responsibility by the principle of strict liability. The principle of strict liability is not on the basis of fault but just a fact. In other words, the corporation must account for his action when there are losses although the case has not been sued in court. In line with Law No 32 Year 2009, Islamic criminal law also recognizes the corporation responsibility represented by its managers. An error principle in Islam explaines that although the criminal perpetrators are not burdened for the criminal liability but the compensation is remain burdened to the offender.
\end{abstract}

Keywords: Accountability, corporation, strict liability, Islamic criminal law.

Abstraks: Dalam konsep hukum pidana, pertanggungjawaban pidana dimaksudkan untuk menentukan apakah seseorang tersangka/terdakwa dipertanggungjawabkan atas suatu tindak pidana yang terjadi atau tidak. Jika ia dipidana, bahwa tindakan yang dilakukan itu bersifat melawan hukum dan terdakwa mampu bertanggungjawab. Namun dalam UU RI No. 32 Tahun 2009 mengatur tentang pertanggungjawaban korporasi terhadap prinsip strict liability. Prinsip strict liability merupakan pertanggungjawaban tanpa atas dasar kesalahan, cukup fakta yang berbicara. Dengan kata lain, korporasi harus mempertanggungjawabkan perbuatannya ketika kerugian itu ada, walaupun kasus tesebut belum diperkarakan di pengadilan. Sejalan dengan UU RI No 32Tahun 2009, hukum pidana Islam juga mengakui pertanggungjawaban korporasi yang diwakilkan oleh pengurusnya. Asas tersalah dalam Islam menjelaskan bahwa walaupun secara pidana pelaku pidana tidak dibebani pertanggungjawaban, namun beban ganti kerugian tetap ditanggung pelaku.

Kata Kunci: Pertanggungjawaban, korporasi, strict liability, hukum pidana Islam 


\section{Pendahuluan}

Istilah lingkungan hidup, dalam bahasa Inggris disebut dengan environment, dalam bahasa Belanda disebut juga dengan milieu atau dalam bahasa Perancis disebut dengan I environment. Yang dimaksud dengan lingkungan hidup adalah semua benda, daya dan kondisi yang terdapat dalam suatu tempat atau ruang tempat manusia atau makhluk hidup berada dan dapat mempengaruhi hidupnya. ${ }^{1}$ Dalam pasal $1 \mathrm{UU}$ RI No.32 tahun 2009 tercantum bahwa Lingkungan hidup adalah kesatuan ruang dengan semua benda, daya, keadaan, dan makhluk hidup, termasuk manusia dan perilakunya, yang mempengaruhi alam itu sendiri, kelangsungan perikehidupan, dan kesejahteraan manusia serta makhluk hidup lain. ${ }^{2}$

Indonesia sendiri telah membuktikan bahwa pentingnya pengelolaan lingkungan hidup dengan jaminan kepastian hukum sejak tahun 1982 dengan diundangkannya UU No.4 Tahun 1982 tentang Ketentuan Pokok-Pokok Pengelolaan Lingkungan Hidup, yang kemudian diubah dengan UU No.23 Tahun 1997 tentang Pengelolaan Lingkungan Hidup, dan diubah kembali dengan UU No.32 Tahun 2009 tentang Perlindungan dan Pengelolaan Lingkungan Hidup. Di dalam UU Lingkungan Hidup tersebut diatur tentang prosedur penyelesaian sengketa lingkungan hidup, cara pengaduan adanya sengketa lingkungan hidup, dan hal-hal lainnya yang berkaitan dengan pertanggungjawaban dalam sengketa lingkungan hidup.

Adapun dalam bahasa asing, pertanggungjawaban pidana disebut sebagai "teorekenbaarheid", "criminal responsibility", "criminal liability". Telah diutarakan bahwa pertanggungjawaban pidana dimaksudkan untuk menentukan apakah seseorang tersangka/terdakwa dipertanggungjawabkan atas suatu tindak pidana (crime) yang terjadi atau tidak. Dengan perkataan lain apakah terdakwa akan dipidana atau dibebaskan. Jika ia dipidana, harus ternyata bahwa tindakan yang dilakukan itu bersifat melawan hukum dan terdakwa mampu bertanggungjawab. Kemampuan tersebut memperlihatkan kesalahan dari petindak yang berbentuk kesengajaan atau kealpaan. ${ }^{3}$

\footnotetext{
${ }^{1}$ N.H.T. Siahaan, Hukum Lingkungan dan Ekologi Pembangunan (Jakarta: Erlangga. 2004), 4.

${ }^{2}$ UU RI No.32 Tahun 2009 Tentang Perlindungan dan Pengelolaan Lingkungan Hidup Lembaran Negara Republik Indonesia Tahun 2009 Nomor 140.

${ }^{3}$ Sianturi, Asas-asas Hukum Pidana di Indonesia dan Penerapannya (Jakarta: Story Grafika, 2002), 250.
} 
Selain orang perorangan yang dapat dituntut pidana, berdasarkan teori hukum pidana modern, maka corporate atau badan hukum (dalam UU Perlindungan dan Pengelolaan Lingkungan Hidup) sebagai legal person merupakan subjek hukum dapat dituntut pidana. ${ }^{4}$ Khusus mengenai pertanggungjawaban korporasi dalam hukum pidana, ternyata terdapat bermacam-macam cara perumusannya yang ditempuh oleh pembuat undang-undang. Berkenaan dengan pembebanan pertanggungjawaban pidana kepada korporasi, terdapat 3 (tiga) sistem yaitu : 1. Pengurus korporasi sebagai pembuat dan penguruslah yang bertanggungjawab, 2. Korporasi sebagai pembuat dan pengurus bertanggungjawab, 3. Korporasi sebagai pembuat dan juga sebagai yang bertanggungjawab. ${ }^{5}$

Mengenai masalah pertanggungjawaban pidana korporasi, asas kesalahan masih tetap dipertahankan, tetapi dalam perkembangan dibidang hukum, khususnya hukum pidana yang menyangkut pertanggungjawaban pidana asas kesalahan atau "asas tiada pidana tanpa kesalahan" tidak mutlak berlaku. Pada pandangan baru ini cukuplah fakta yang menderitakan si korban dijadikan dasar untuk menuntut pertanggungjawaban pidana pada si pelaku sesuai dengan adagium "res ipsa loquitur", fakta sudah berbicara sendiri. Prinsip tanggung jawab mutlak (no-fault liability or liability without fault) di dalam kepustakaan biasanya dikenal dengan ungkapan "absolute liability" atau "strict liability". Dengan prinsip tanggung jawab tanpa keharusan untuk membuktikan adanya kesalahan. Atau dengan perkataan lain, suatu prinsip tanggung jawab yang memandang "kesalahan" sebagai suatu yang tidak relevan untuk dipermasalahkan apakah pada kenyataan ada atau tidak. $^{6}$

Hukum Islam mengatur bahwa pertanggungjawaban pidana berarti manusia harus bertanggungjawab atas akibat dari perbuatan haram yang dilakukannya ketika ia memiliki kebebasan berkehendak (tidak dipaksa) dan mengetahui arti serta akibat perbuatan tersebut. ${ }^{7}$

\footnotetext{
${ }^{4}$ Syahrul Machmud, Penegakan Hukum lingkungan di Indonesia (Yogyakarta: Graha llmu. 2012), 137.

${ }^{5}$ Muladi, Pertanggungjawaban Korporasi dalam Hukum Pidana (Bandung: Sekolah Tinggi Hukum Bandung, 1991), 67.

${ }^{6}$ Muladi \& Dwidja Priyatno, Pertanggungjawaban Pidana Korporasi (Jakarta: Kencana. 2010), 111.

${ }^{7}$ Tim Tsalisah, Ensiklopedi Hukum Pidana Islam (Bogor: Kharisma Ilmu,), 66.
} 
Berdasarkan firman Allah dalam surat ar-Rûm ayat $41^{8}$ dijelaskan bahwa perusak tanaman, pemusnahan binatang, dan segala perbuatan yang merusak lingkungan hidup merupakan larangan agama. Misalnya saja, pencemaran akibat limbah industri akan mengendap melalui air, udara dan sebagainya dan mengakibatkan berbagai penyakit bagi manusia. Karena Allah SWT telah menjadikan bumi dan langit sebagai tempat kehidupan manusia dan seluruh isinya diperuntukkan untuk manusia. ${ }^{?}$

Hukum Islam sejak kelahirannya telah mengenal badan-badan hukum. Hukum Islam menjadikan badan-badan hukum ini memiliki hak dan tasarruf (melakukan tindakan hukum), tetapi hukum Islam tidak menjadikan badan hukum tersebut sebagai objek pertanggungjawaban pidana karena pertanggungjawaban ini didasarkan atas adanya pengetahuan dan pilihan, sedangkan keduanya tidak terdapat pada badan-badan hukum tersebut. Badan hukum dapat dijatuhi hukuman bila hukuman tersebut dijatuhkan kepada pengelolanya, seperti hukuman pembubaran, penghancuran, penggusuran dan penyitaan. ${ }^{10}$ Dalam hukum Islam dikenal dengan asas tersalah yakni ketidakhati-hatian dan ketidakwaspadaan.

\section{Pertanggungjawaban Pidana dalam Hukum Pidana Islam}

Hukum Islam menjelaskan, pertanggungjawaban pidana berarti manusia harus bertanggung jawab atas akibat dari perbuatan haram yang dilakukannya ketika ia memiliki kebebasan berkehendak (tidak dipaksa) dan mengetahui arti serta akibat perbuatan tersebut. ${ }^{11}$

Berdasarkan defenisi pertanggungjawaban pidana di atas dapat disimpulkan bahwa unsur-unsur pertanggungjawaban pidana dalam hukum Islam terdiriatas; manusia, perbuatan, pilihan dan pengetahuan, serta akibat yang timbul (korban). Adapun dalam hukum Islam pertanggungjawaban pidana ditegakkan di atas tiga hal:

a) Pelaku melakukan perbuatan yang dilarang;

b) Pelaku mengerjakan dengan kemauan sendiri;

\footnotetext{
${ }^{8}$ Telah nampak kerusakan di darat dan di laut disebabkan Karena perbuatan tangan manusia, supaya Allah merasakan kepada mereka sebahagian dari (akibat) perbuatan mereka, agar mereka kembali (ke jalan yang benar).

${ }^{9}$ Tim Tsalisah, Ensiklopedia Hukum Pidana Islam, 1014.

${ }^{10}$ Ibid., 67.

${ }^{11}$ Ibid., 66
} 
c) Pelaku mengetahui akibat perbuatannya.

Jika ketiga dasar ini ada, pertanggungjawaban pidana juga ada. Adapun jika ada satu diantaranya tidak ada, pelaku tidak dijatuhi hukuman atas perbuatannya. Tidak adanya penjatuhan hukuman dalam segala keadaan tidak dikarenakan oleh satu sebab itu saja. Apabila suatu perbuatan tidak dilarang, tidak ada pertanggungjawaban pidana secara mutlak karena perbuatan tersebut tidak dilarang. Pertanggungjawaban pidana sebenarnya tidak ada kecuali setelah pelaku melakukan perbuatan yang dilarang. Jika suatu perbuatan dilarang, tetapi pelakunya tidak mempunyai pengetahuan dan pilihan, pertanggungjawaban pidana ada, tetapi pelaku terhapus dari penjatuhan hukuman karena tidak adanya dua hal tersebut.

Hukum Islam mensyaratkan keadaan si pelaku harus memiliki pengetahuan dan pilihan. Maka dari itu dalam Islam ada dua objek pertanggungjawaban pidana yaitu; pertama, manusia. Manusia yang menjadi objek pertanggungjawaban pidana adalah yang masih hidup, sedangkan yang sudah mati tidak mungkin menjadi objek karena dua syarat tersebut tidak lagi terdapat pada dirinya. Lebih dari itu, kaidah hukum Islam menetapkan bahwa kematian menggugurkan pembebanan hukum. Manusia yang dibebani tanggung jawab pidana dan yang memenuhi dua syarat tersebut adalah orang yang berakal, balig dan memiliki kebebasan berkehendak. Kedua, badan-badan hukum. Dalam hukum Islam, badan-badan hukum ini memiliki hak dan tasarruf (melakukan tindakan hukum), tetapi hukum Islam tidak menjadikan badan hukum tersebut sebagai objek pertanggungjawaban pidana karena pertanggungjawaban ini didasarkan atas adanya pengetahuan dan pilihan, sedangkan keduanya tidak terdapat pada badan-badan hukum tersebut. Adapun bila terjadi perbuatan yang dilarang dari orang yang mengelola lembaga tersebut, orang itulah yang bertanggung jawab atas tindak pidananya. Badan hukum dapat dijatuhi hukuman bila hukuman tersbut dijatuhkan kepada pengelolanya, seperti hukuman pembubaran, penghancuran, penggusuran dan penyitaan. Demikian pula kativitas badan hukum yang dapat membahayakan dapat dibatasi demi melindungi keamanan dan ketentraman masyarakat.

Telah diketahui bahwa pelanggaran (melawan hukum) adakalanya disengaja dan tidak disengaja (tersalah). Perbuatan melawan hukum 
terbagi menjadi disengaja dan tidak disengaja, masing-masing terbagi dua berdasarkan tingkat ukurannya. Perbuatan disengaja terbagi menjadi "disengaja" dan "mirip disengaja", sedangkan perbuatan tersalah terbagi menjadi "tersalah" dan "perbuatan yang dianggap tersalah". Selanjutnya, perbuatan melawan hukum terbagi menjadi empat sehingga pertanggungjawaban pidana juga terbagi menjadi empat yaitu:

a) Disengaja; arti umum "disengaja" adalah si pelaku berniat melakukan suatu perbuatan yang dilarang tersebut. Kemaksiatan yang disengaja adalah perbuatan melawan hukum yang paling berat dan hukum Islam menjatuhkan hukuman (pertanggungjawaban pidana) yang paling berat atasnya.

b) Menyerupai disengaja; hukum Islam tidak mengenal istilah "mirip disengaja" kecuali pada kasus pembunuhan dan tindak pidana penganiayaan fisik yang tidak sampai menyebabkan kematian. Pengertian "tindak pidana yang mirip disengaja" dalam kasus pembunuhan/penganiayaan yaitu melakukan suatu perbuatan yang dapat menghilangkan nyawa dan pelaku hanya bermaksud menyerang, tanpa berniat membunuh/menganiayanya. Akan tetapi, perbuatannya itu mengakibatkan kematian.

c) Tersalah (tidak disengaja); kemaksiatan tersalah adalah jika si pelaku melakukan perbuatan tanpa bermaksud memperbuat kemaksiatan, namun ia tersalah.

d) Yang dianggap tersalah; kemaksiatan yang dianggap tersalah terdapat pada dua keadaan. Pertama, pelaku tidak bermaksud melakukan suatu perbuatan, tetapi perbuatan itu terjadi akibat kelalaiannya. Kedua, si pelaku menjadi penyebab tidak langsung terjadinya perbuatan yang dilarang dan ia tidak bermaksud melakukannya. Dalam konteks ini, kemaksiatan tersalah lebih besar daripada kemaksiatan yang dianggap tersalah karena pelaku kemaksiatan tersalah melakukan perbuatan dengan sengaja sehingga menimbulkan akibat yang dilarang karena kelalaian dan ketidakhati-hatiannya. Adapun pada kasus yang dianggap tersalah, si pelaku tidak menyengaja perbuatan itu, namun perbuatan itu terjadi akibat kelalaiaannya dan disebabkan olehnya.

Pertanggungjawaban pidana dapat terhapuskan karena sebab yang berkaitan dengan perbuatan yakni perbuatan yang dilakukan adalah perbuatan yang mubah (tidak dilarang), atau yang berkaitan dengan 
keadaan diri pelaku yakni perbuatan tersebut tetap dilarang, tetapi pelaku tidak dijatuhi hukuman ketika melakukannya. Berikut empat kondisi atau sebab dihapuskannya hukuman, yaitu:

e) Paksaan: perbuatan yang diperbuata oleh seseorang karena (pengaruh) orang lain. Karena itu, hilang kereelaannya dan merusak (tidak sempurna) pilihannya. Atau suatu perbuatan yang timbul/keluar dari pemaksa dan menimbulkan pada diri orang yang dipaksa suatu keadaan yang mendorong dirinya untuk mengerjakan perbuatan yang dituntut (oleh pemaksa) darinya. Paksaan dibagi menjadi dua macam yaitu: Pertama, paksaan yang menghilangkan kerelaan dan merusak pilihan (orang yang dipaksa). Paksaan jenis ini dikhawatirkan akan menghabiskan nyawa orang yang dipaksa. Paksaan jenis ini dinamakan "paksaan absolute" (ikrâh tâm). Kedua, paksaan yang menghilangkan kerelaan, tetapi tidak sampai merusak pilihan (orang yang dipaksa). Dalam paksaan ini biasanya tidak dikhawatirkan akan mengakibatkan hilangnya nyawa, seperti ancaman dipenjarakan atau diikat untuk waktu yang singkat atau dipukul dengan pukulan yang tidak dikhawatirkan dapat merusak (pukulan-pukulan ringan). Paksaan jenis ini dinamakan paksaan relatif atau paksaan tidak berat.

Adapun syarat-syarat yang harus dipenuhi dalam hal paksaan adalah: Ancaman bersifat mulji' yakni yang akan mengakibatkan bahaya yang besar (ancaman yang menyangkut keselamatan jiwa atau anggota badan) sehingga dapat menghapuskan kerelaan, seperti pembunuhan, pukulan yang keras, pengikatan dan penahanaan dalam waktu yang lama. Ancaman harus berupa perbuatan yang dilarang, yakni yang tidak disyariatkan. Ancaman harus seketika (mesti hampir terjadi saat itu juga) yang dikhawatirkan akan dilakukan jika orang yang dipaksa tidak melaksanakan perintah pemaksa. Orang yang memaksa (mengancam) harus memiliki kemampuan untuk melaksanakan ancamannya sebab paksaan tidak akan terlaksana kecuali dengan adanya kemampuan. Orang yang menghadapi ancaman (dipaksa) harus meyakini bahwa ancaman yang diterimanya benar-benar akan dilaksanakan oleh orang yang memaksanya apabila kehendak si pemaksa tidak dipenuhinya.

f) Mabuk adalah: hilangnya akal pikiran karena mengonsumsi khamar atau yang sejenisnya atau keadaan seseorang yang perkataannya 
banyak tidak keruan. Pendapat yang kuat dalam mazhab yang empat menetapkan bahwa orang yang mabuk tidak dijatuhi hukuman atas tindak pidana yang dilakukannya apabila ia meminumnya karena dipaksa (terpaksa) atau meminumnya karena kehendak sendiri, tetapi ia tidak tahu bahwa minuman itu memabukkan, atau ia meminum obat untuk mengobati dirinya kemudian membuatnya mabuk dan melakukan tindak pidana. Hal ini karena ia melakukan tindak pidana dalam keadaan hilang pikirannya sehingga ia dihukumi seperti orang gila atau orang yang tidur atau yang seumpamanya.

g) Gila adalah hilangnya akal, rusaknya akal, atau lemahnya akal. Berikut macam-macam gila:

i. Gila yang terus-menerus yaitu suatu keadaan pada diri seseorang dimana ia tidak dapat berpikir sama sekali atau gila secara menyeluruh dan terus-menerus, baik itu bawaan yang diderita sejak lahir maupun bukan. Orang yang menderita junûn mutbaq tidak bertanggungjawab secara pidana karena gilanya terjadi secara sempurna dan terus-menerus.

ii. Gila yang berselang/kambuhan yaitu keadaan orang yang tidak dapat berpikir sama sekali, tetapi gilanya tidak terus-menerus. Terkadang ia kambuhdan terkadang ia sembuh. Jika sedang kambuh akalnya akan hilang secara sempurna, namun jika telah sembuh, akalnya kembali normal. Orang yang menderita gila kambuhan tidak bertanggung jawab secara pidana ketika gilanya sedang kambuh, sedangkan jika akalnya sudah kembali normal, ia tetap akan dikenai tanggung jawab pidana atas tindak pidana yang dilakukannya.

iii. Gila sebagian yaitu gila yang tidak secara keseluruhan atau gila (tidak dapat berpikir) yang hanya sebatas pada satu aspek atau lebih.dalam hal ini,sipenderita kehilangan kekuatan berpikirnya dalam satu atau beberapa aspek (perkara) tertentu saja, tetapi ia dapat menggunakannya pada perkara lainnya. Orang yang gila sebagian ini tetap dikenai tanggung jawab pidana atas apa yang dapat dijangkau oleh akalnya dan tidak bertanggung jawab pada apa yang tidak dijangkaunya.

iv. Dungu yaitu keadaan yang sedikit pemahamannya, kacau pembicaraannya, dan rusak penalarannya, baik timbul karena sakit 
maupun pembawaan sejak lahir. Orang dungu akan diampuni dari tanggung jawab pidana.

v. Epilepsi dan histeria (ganguaan saraf) yaitu kondisi-kondisi dan gejala gangguan urat saraf yang tampak pada orang yang menderita sakit tersebut. Orang tersbutakan kehilangan perasaan, pilihan (ikhtiyâr), dan kekuatan berpikirnya. Para penderita penyakit tersebut dihukumi seperti orang yang terpaksa: mempunyai kekuatan berpikir tetapi tidak mempunyai pilihan. Jika kekuatan berpikir (akal) dan pilihan (ikhtiyâr) mereka tidak hilang, mereka bertanggungjawab secara pidana atas perbuatan mereka.

h) Anak belum dewasa (anak di bawah umur);

Hukum Islam dipandang sebagai hukum pertama di dunia yang membedakan secara sempurna antara anak kecil dan orang dewasa dari segi tanggung jawab pidana. Hukum Islam juga merupakan hukum pertama yang meletakkan tanggung jawab anakanak yang tidak berubah dan berevolusi sejak dikeluarkannya. Fasefase yang dilalui manusia dari sejak lahir sampai usia dewasa terdiri atas tiga fase yakni: yang pertama fase tidak adanya kemampuan berpikir (idrâk). fase ini dimulai sejak manusia dilahirkan dan berakhir sampai usia tujuh tahun. Apabila anak kecil melakukan tindak pidana apapun sebelum ia berusia tujuh tahun, dia tidak dihukum, baik pidana maupun hukuman ta'dîbiy (hukuman untuk mendidik). Anak kecil tidak dijatuhi hukuman hudûd, qisâs, dan ta'zîr apabila dia melakukan tindak pidana hudûd dan tindak pidana qisâs. Walaupun begitu tanggung jawab perdata dalam hal ganti rugi harta dan jiwa seseorang tetap menjadi tanggung jawab mereka. Yang kedua fase kemampuan berpikir lemah. Fase ini dimulai sejak sianak menginjak usia tujuh tahun sampai ia mencapai usia baligh (yang dibatasi oleh para fuqoha' pada usia lima belas tahun). Dalam fase ini, anak kecil yang telah mumayyiz tidak bertanggung jawab secara pidana atas atas tindak pidana yang dilakukannya. Ia tidak dijatuhi hukuman hudûd bila ia mencuri atau berzina misalnya. Dia juga tidak dihukum qisâs sila membunuh atau melukai, tetapi dikenai tanggung jawab ta'dîbi, yaitu hukuman yang bersifat mendidik atas pidana yang dilakukannya. Dan fase yang ketiga adalah kekuatan 
berpikir penuh (sempurna). Fase ini dimulai sejak si anak menginjak usia kecerdasan (dewasa), yaitu kala menginjak usia lima belas tahun. Pada fase ini, seseorang dikenai tanggung jawab pidana atas tindak pidana yang dilakukannya apapun jenisnya. ${ }^{12}$

\section{Pertanggungjawaban dan Pemidanaan Kasus Kerusakan Lingkungan Hidup dalam Hukum Pidana Islam}

Manusia adalah makhluk yang paling dimuliakan Allah swt. Allah menciptakannya dengan tangan (kekuasaan)-Nya sendiri, meniupkan ruh dari-Nya kepadanya, memerintahkan sujud semua Malaikat kepadanya, menundukkan semua apa yang ada di langit dan di bumi kepadanya, menjadikannya sebagai khalifah-Nya di bumi, dan membekalinya dengan kekuatan serta bakat-bakat agar ia dapat menguasai bumi ini, dan supaya ia dapat meraih dengan semaksimal kemampuannnya akan kesejahteraan kehidupan material dan spiritualnya. Karena itulah, setiap penghapusan atau pengurangan atas hak manusia dianggap sebagai tindak kriminal (pelanggaran). ${ }^{13}$

Ulama berpendapat bahwa perusak lingkungan, baik lingkungan biotik, seperti flora dan fauna, maupun abiotik seperti, air, sungai, dan pegunungan adalah perilaku yang dilarang keras dalam ajaran Islam. Perilaku yang merusak lingkungan itu, seperti dikemukakan oleh informan, dapat diklasifikasikan menjadi empat macam perilaku, yaitu: membuang hajat di jamban (WC Terapung), membuang sampah sembarangan, membangun pemukiman di bantaran sungai, serta menambang hasil bumi dan menebang pohon tanpa memperhatikan dampak lingkungan, ${ }^{14}$ seperti firman Allah swt dalam surat al-Qashash: 83

Negeri akhirat itu, kami jadikan untuk orang-orang yang tidak ingin menyombongkan diri dan berbuat kerusakan di (muka) bumi. Dan kesudahan (yang baik) itu adalah bagi orang-orang yang bertakwa ${ }^{15}$

Delik lingkungan adalah perintah dan larangan undang-undang kepada subjek hukum yang jika dilanggar diancam dengan penjatuhan

\footnotetext{
12 Ibid, 255-257.

${ }^{13}$ Sayyid Sabiq, Fikih Sunnah, (Terj: H. A. Ali, Fikih Sunnah 10, Bandung: PT. Alma'arif, 1987), 9.

${ }^{14}$ Sukarni, Fikih Lingkungan Hidup Perspektif Ulama Kalimantan Selatan, Jakarta: Kementrian Agama RI, 2011), 132-142.

${ }^{15}$ Departemen Agama Republik Indonesia, Al-Qur'an dan Terjemahan, 619.
} 
sanksi-sanksi pidana, antara lain pemenjaraan dan denda, dengan tujuan untuk melindungi lingkungan hidup secara keseluruhan maupun unsurunsur dalam lingkungan hidup seperti hutan satwa, lahan, udara, dan air serta manusia. ${ }^{16}$ Prof. Dr. St. Munadjat Danusaputro, mengartikan lingkungan hidup sebagai semua benda dan kondisi, termasuk di dalamnya manusia dan tingkah perbuatannya, yang terdapat dalam ruang tempat manusia berada dan mempengaruhi hidup serta kesejahteraan dan jasad hidup lainnya.

Salah satu wujud perbuatan yang merugikan orang/pihak lain ialah pencemaran lingkungan yang dalam istilah lain disebut juga sebagai kerusakan lingkungan. Jadi, pencemaran lingkungan atau perusakan lingkungan, maupun apa saja yang dikategorikan merugikan orang/pihak lain dalam kepentingan lingkungan hidupnya, termasuk sebagai perbuatan melawan hukum (onrechtsmatigedaad). ${ }^{17}$

\section{Konsep Pertanggungjawaban Korporasi terhadap Penerapan Prinsip Strict Liability dalam Kasus Kerusakan Lingkungan Hidup Menurut UU No 32 Tahun 2009}

Disebutkan dalam bahasa asing pertanggungjawaban pidana disebut sebagai "toerekenbaarheid", "criminal responsibility", "criminal liability". Pertanggungjawaban pidana dimaksudkan untuk menentukan apakah seseorang tersangka/terdakwa dipertanggungjawabkan atas suatu tindak pidana yang terjadi atau tidak. Petindak di sini adalah orang bukan makhluk lainnya. ${ }^{18}$

Seiring berjalannya waktu dan penggalian terhadap ilmu hukum pidana, manusia bukanlah satu-satunya subjek hukum. Diperlukan suatu hal lain yang menjadi subjek hukum pidana. Disamping orang dikenal subjek hukum selain manusia yang disebut Badan Hukum. Badan Hukum adalah organisasi atau kelompok manusia yang mempunyai tujuan tertentu yang dapat menyandang hak dan kewajiban. Negara dan perseroan terbatas misalnya adalah organisasi atau kelompok manusia yang merupakan badan hukum. Badan hukum dibedakan menjadi dua bentuk yaitu: 1) Badan hukum dalam lingkungan hukum publik, yaitu

\footnotetext{
${ }^{16}$ Takdir Rahmadi, Hukum Lingkungan dilndonesia, (Jakarta: Rajawali Pers, 2012), 221.

${ }^{17} \mathrm{NHT}$. Siahaan, Hukum Lingkungan dan Ekologi Pembangunan, 4.

${ }^{18}$ Sianturi, Asas-Asas Hukum Pidana di Indonesia dan Penerapannya, 250.
} 
badan-badan yang pendiriannya dan tatanannya ditetukan oleh hukum publik, yang dibentuk oleh penguasa berdasarkan perundang-undangan, dan 2) Badan hukum dalam lingkungan hukum privat, yaitu badanbadan yang pendirian dan tatanannya ditentukan oleh hukum privat, yang didirikan oleh pribadi orang untuk tujuan tertentu. ${ }^{19}$

Korporasi sebagai pelaku perbuatan pidana tidak dikenal dalam Kitab Undang-Undang Hukum Pidana (KUHP), karena dalam KUHP dikenal asas atau adagium "actus non facit reum, nisi mens sit rea" atau "tiada pidana tanpa kesalahan". Asas ini mengandung konsekuensi bahwa yang dapat dimintai pertanggungjawaban pidana hanyalah yang memiliki kalbu saja yaitu manusia, badan hukum tidak memiliki kalbu maka tidak dapat dimintai pertanggungjawaban pidana. ${ }^{20}$ Bertitik tolak pada prinsip asas "tiada pidana tanpa kesalahan", maka beberapa isi rumusan perumusan perundang-undangan pidana itu mengakui badan hukum (korporasi) sebagai subjek tindak pidana, tetapi hanya saja yang dapat dipertanggungjawabkan secara pidana adalah pengurus berdasarkan kuasa dari badan hukum.

Perkembangan kemudian, secara teoritis (menurut doktrin) bahwa badan hukum sebagai subjek tindak pidana dapat dipertanggungjawabkan secara pidana, yaitu sebagai berikut: a) Dapat dikenakan terhadap korporasi (badan hukum) itu sendiri; b) Dikenakan kepada mereka yang memberi perintah atau yang bertindak sebagai pemimpin dalam perbuatan tindak pidana (pengurus); c) Dikenakan baik terhadap korporasi maupun mereka yang memberi perintah atau yang bertindak sebagai pemimpin dalam perbuatan melakukan tindak pidana tersebut (pengurus) atau kedua-duanya, yaitu badan hukum dan pengurus. ${ }^{21}$

Membuktikan adanya kesalahan tidaklah mudah karena harus lebih dulu dibuktikan adanya hubungan sebab akibat (causality) antara perbuatan pencemaran dengan kerugian dari si penderita. Khususnya bagi masalah lingkungan, hal membuktikan atau menjelaskan hubungan sebab akibat dari perbuatan si poluter dengan korban, merupakan hal yang sulit. Menganalisis suatu pencemaran membutuhkan penjelasan

\footnotetext{
19 Sherief Maronie, http://zriefmaronie.blogspot.com/2012/12/subjek-hukum-pidana.html, 7 Des 2012

${ }^{20}$ Syahrul Machmud, Penegakan Hukum Lingkungan Indonesia, 141.

21 Etty Utju R.Koesoemahatmadja, Hukum Korporasi (Penegakan Hukum Terhadap Pelaku Economic Crimes dan Perlindungan Abuse of Power)(Bogor: Ghalia Indonesia, 2011), 66.
} 
yang bersifat ilmiah, teknis dan khusus (transfrontier) sehingga bila skalanya bersifat meluas dan serius, maka membuktikan hubungan sebab akibat dalam kasus pencemaran justru lebih menyulitkan. Oleh karena itu, penerapan sistem tanggungjawab yang bersifat biasa tidaklah mencerminkan rasa keadilan. ${ }^{22}$ Dalam hal tindak pidana kerusakan lingkungan yang diakibatkan oleh kegiatan korporasi dalam Pasal 88 UUPPLH sudah mengatur secara tegas mengenai strict liability: ${ }^{23}$

"Setiap orang yang tindakannya, usahanya, dan/atau kegiatannya menggunakan B3, menghasilkan dan/atau mengelola limbah B3, dan/atau yang menimbulkan ancaman serius terhadap lingkungan hidup bertanggung jawab mutlak atas kerugian yang terjadi tanpa perlu pembuktian unsur kesalahan."

Yang dimaksud dengan strict liability adalah pembuat sudah dapat dipidana jika telah melakukan perbuatan sebagaimana dirumuskan dalam undang-undang tanpa melihat bagaimana sikap batinnya, yaitu dapat diartikan pula sebagai "liability without fault" (pertanggungjawaban tanpa kesalahan).

Pertanggungjawaban korporasi tindak pidana lingkungan harus memperhatikan hal berikut: ${ }^{24}$

1. Korporasi mencakup baik badan hukum (legal entity) maupun nonbadan hukum seperti organisasi dan sebagainya.

2. Korporasi dapat bersifat privat (private yuridical entity) dan dapat pula bersifat publik (public entity).

3. Apabila diidentifikasikan bahwa tindak pidana lingkungan dilakukan dalam bentuk organisasional, maka orang alamiah (managers, employess) dan korporasi dapat dipidana baik sendiri-sendiri maupun bersama-sama (bi-punishment provision).

4. Terdapat kesalahan manajemen dalam korporasi dan terjadi apa yang dinamakan breach of a statutory or regulatory provision.

5. Pertanggungjawaban badan hukum dilakukan terlepas dari apakah orang-orang yang bertanggungjawab di dalam badan hukum tersebut berhasil diidentifikasi, dituntut, dan dipidana.

\footnotetext{
${ }^{22}$ NHT. Siahaan, Hukum Lingkungan dan Ekologi Pembangunan, 311.

${ }^{23}$ UU RI No 32 Tahun 2009 tentang Perlindungan dan Pengelolaan Lingkungan Hidup Lembaran Negara Republik Indonesia Tahun 2009 Nomor 140.

${ }^{24}$ Etty Utju R.Koesoemahatmadja, Hukum Korporasi dan Penegakan Hukum terhadap Pelaku Economic Crimes dan Perlindungan Abuse of Power, 88.
} 
6. Segala sanksi pidana dan tindakan pada dasarnya dapat dikenakan pada korporasi, kecuali pidana mati dan pidana penjara.

7. Penerapan sanksi pidana terhadap korporasi tidak menghapuskan kesalahan perorangan.

8. Pemidanaan terhadap korporasi hendaknya memerhatikan kedudukan korporasi untuk mengendalikan perusahaan, melalui kebijakan pengurus atau para pengurus (corporate executive officers) yang memiliki kekurangan untuk memutuskan (power of decision) dan keputusan tersebut telah diterima (accepted) oleh korporasi tersebut.

UUPPLH mengakui tentang tanggungjawab korporasi seperti diatur dalam Pasal 116 sampai 119. Berdasarkan pasal 117, jika tindak pidana dilakukan oleh atau atas nama badan hukum, perseroan, perserikatan yayasan atau organisasi lain, ancaman pidananya diperberat sepertiga. Di samping pidana denda, korporasi yang melakukan tindak pidana bisa dijatuhkan hukuman pokok berupa denda dan hukuman tambahan berupa tindakan tata tertib sebagai berikut: ${ }^{25}$

a. Perampasan keuntungan yang diperoleh dari tindak pidana (fruit of crime);

b. Penutupan seluruhnya atau sebagian perusahaan;

c. Perbaikan akibat tindak pidana;

d. Mewajibkan mengerjakan apa yang dilakukan tanpa hak;

e. Meniadakan apa yang dilalaikan tanpa hak;

f. Menempatkan perusahaan di bawah pengampuan paling lama 3 (tiga) tahun.

Karena rumusan Pasal 119 UUPPLH tersebut tidak secara tegas menyebutkan apakah jenis hukuman ini alternatif atau dapat dikenakan dua atau lebih sekaligus, penulis berpendapat jenis-jenis hukuman itu dapat dikenakan dua atau lebih sekaligus tergantung pada kasus perkasus atau akibat-akibat dari pelanggaran.

Ganti rugi dalam strict liability biasanya dikaitkan dengan sistem plafond atau ceiling (batas maksimalisasi tanggung jawab). Ini berarti bahwa pihak yang bertanggung jawab hanya dibebankan sampai dengan batas tertentu. Indonesia tampaknya menganut paham plafond atau ceiling dalam strict liability karena dalam penjelasan Pasal 35 ayat (1) UUPLH maupun dalam penjelasan Pasal 88 UUPPLH dijelaskan bahwa

\footnotetext{
${ }^{25}$ Sukanda Husin, Penegakan Hukum Lingkungan Indonesia (Jakarta:Sinar Grafika, 2009), 124.
} 
besarnya nilai ganti rugi yang dapat dibebankan terhadap pencemar atau perusak lingkungan hidup dapat ditetapkan sampai batas tertentu. Pengertian sampai batas tertentu ialah jika menurut peraturan perundang-undangan yang berlaku, ditentukan keharusan asuransi bagi usaha dan/atau kegiatan yang bersangkutan atau telah tersedia dana lingkungan hidup. ${ }^{26}$

Berdasarkan prinsip ini, si pelaku atau polluter telah cukup untuk dinyatakan bertanggungjawab atas pencemaran atau perusakan lingkungan, meskipun belum dinyatakan bersalah. Dalam asas strict liability, kesalahan (fault, scuhld, atau mens rea) tidaklah menjadi penting untuk menyatakan si pelaku bertanggung jawab karena pada saat peristiwa itu timbul ia sudah memikul suatu tanggung jawab. Adapun manfaat dari asas strict liability ini adalah: ${ }^{27}$

1. Pentingnya jaminan untuk mematuhi peraturan-peraturan penting tertentu yang diperlukan untuk kesejahteraan masyarakat;

2. Bukti kesalahan sangat sulit didapat atas pelanggaran-pelanggaran peraturan yang berhubungan dengan kesejahteraan masyarakat;

3. Tingkat bahaya sosial yang tinggi yang timbul dari perbuatanperbuatan itu.

Dengan digunakannya strict liability sebagai sistem hukum yang baru, hambatan-hambatan yang dialami pihak penderita dapat diterobos. Berdasarkan sistem ini, pembuktian tidak lagi dibebankan pada pihak pengklaim (korban yang dirugikan), sebagaimana yang selama ini lazim dianut, tetapi dibebankan pada pihak pelaku perbuatan melawan hukum. Di sini berlaku asas pembuktian terbalik (Omkerings van Bewijslast).

Tinjauan Hukum Pidana Islam terhadap Pertanggungjawaban Korporasi terhadap Penerapan Prinsip Strict Liability dalam Kasus Lingkungan Hidup Menurut UU No 32 Tahun 2009

Dalam hukum Islam perbuatan (tindak) pidana disebut sebagai jarîmah, yaitu larangan-larangan shara' yang diancam oleh Allah dengan

\footnotetext{
${ }^{26}$ NHT.Siahaan, Hukum Lingkungan dan Ekologi Pembangunan, 276.

27 Ibid, 317.
} 
had atau ta'zîr ${ }^{28}$ Sedangkan unsur-unsurnya dapat dikategorikan telah berbuat jarimah meliputi: ${ }^{29}$

1. Nas yang melarang perbuatan dan mengancam hukuman terhadapnya. Dan unsur ini biasanya disebut sebagai "unsur formil" (rukun syar'i).

2. Adanya tingkah laku yang membentuk jarimah, baik berupa perbuatan-perbuatan nyata ataupun sikap tidak berbuat, dan unsur ini biasa disebut "unsur material" (rukun maddi).

3. Pembuat adalah orang mukhallaf, yaitu orang yang dapat dimintai pertanggungjawaban terhadap jarimah yang diperbuatnya. Dan unsur ini biasa disebut "unsur moril" (rukun adabi). Dengan adanya unsurunsur tersebut maka apabila seseorang melakukan suatu perbuatan yang tergolong jarîmah, maka orang tersebut akan dapat dikenakan 'uqûbahnya.

Sejalan dengan peraturan tentang tindak pidana lingkungan hidup yang diatur di dalam undang-undang lingkungan hidup, di dalam hukum Islam juga diatur tentang larangan perbuatan tersebut. Seperti firman Allah swt dalam surat al-A'raf ayat $56 .^{30}$

Hukum Islam sejak kelahirannya telah mengenal badan-badan hukum. Hukum Islam menjadikan badan-badan hukum ini memiliki hak dan tasarruf (melakukan tindakan hukum), tetapi hukum Islam tidak menjadikan badan hukum tersebut sebagai objek pertanggungjawaban ini didasarkan atas adanya pengetahuan dan pilihan, sedangkan keduanya tidak terdapat pada badan-badan hukum tersebut. Adapun bila terjadi perbuatan yang dilarang dari orang yang mengelola lembaga tersebut, orang itulah yang bertanggungjawab atas tindak pidananya. Badan hukum dapat dijatuhi hukuman bila hukuman tersebut dijatuhkan kepada pengelolanya, seperti hukuman pembubaran, penghancuran, penggusuran, dan penyitaan. Demikian pula aktivitas badan hukum yang dapat membahayakan dapat dibatasi demi melindungi keamanan dan ketentraman masyarakat. ${ }^{31}$

\footnotetext{
${ }^{28}$ A. Hanafi, Asas-Asas Hukum Pidana Islam, Cet-3 (Jakarta:Bulan Bintang, 1990), 1.

${ }^{29}$ Ibid, 6.

${ }^{30}$ Dan janganlah kamu membuat kerusakan di muka bumi, sesudah (Allah) memperbaikinya dan berdoalah kepada-Nya dengan rasa takut (Tidak akan diterima) dan harapan (akan dikabulkan). Sesungguhnya rahmat Allah amat dekat kepada orang-orang yang berbuat baik.

${ }^{31}$ Tim Tsalisah, Ensiklopedi Hukum Pidana Islam, 67.
} 
Hukum Islam mengatur tentang asas tersalah yakni ketidakhatihatian dan ketidakwaspadaan. Setiap perbuatan tersalah tidak dijatuhi hukuman karena, ketersalahan telah menghapuskan salah satu unsur pidana, yaitu unsur kesengajaan. Hanya saja terhapusnya pertanggungjawaban pidana karena tidak adanya salah satu unsur asasi pidana tidak menghalangi pertanggungjawaban secara perdata karena kaidah hukum Islam menetapkan bahwa darah dan harta benda dilindungi dan mendapat jaminan keselamatan (maşûm) dan alasanalasan syar'i tidak bertentangan (tidak menghapuskan) jaminan keselamatan tersebut. Tersalah dalam hukum Islam terbagi dua macam: ${ }^{32}$ 1. Tersalah yang terlahir (al-khata' al-mutawallid); adalah tersalah yang terlahir dari suatu perbuatan yang tidak dilarang (mubah) atau dari perbuatan pelaku yang disangka tidak dilarang.

2. Tersalah yang tidak terlahir (al-khata' ghair mutawallid); adalah setiap pidana tersalah selain al-khata al-mutawallid.

Pada dasarnya, asas tersalah menurut hukum Islam adalah ketidakhati-hatian dan ketidakwaspadaan. Kendati demikian, tidak disyaratkan terjadinya kelalaian untuk menuntut pertanggungjawaban pelaku di semua keadaan tersalah. Terjadinya kelalaian hanya disyaratkan pada keadaan al-khata' al-mutawallid. Adapun pada keadaan lainnya, kelalaian tidak terbebaskan dari tanggungjawab pidana kecuali telah terbukti adanya unsur keterpaksaan. ${ }^{33}$ Dengan demikian, terlihat bahwa dalam penerapan asas tersalah dalam hukum pidana Islam merupakan penggantian kerugian secara mutlak atau utuh. Karena kemaslahatan masyarakat menjadi pertimbangan dalam penjatuhan hukuman atas kasus tersalah karena diantara tindak pidana tersalah terdapat tindak pidana yang berbahaya yang acap kali terjadi. Karena dasar tersalah adalah kelalaian dan ketidakhati-hatian, Shâri' menjatuhkan hukuman atas tindak pidana tersalah yang acap kali terjadi dan jelas bahayanya, sebab menjatuhkan hukuman atasnya dapat mewujudkan kemaslahatan masyarakat yang dapat membuat seseorang menjadi hati-hati dan tidak sembrono sehingga tindak pidana jenis ini menjadi berkurang.

\footnotetext{
${ }^{32} \mathrm{lbid}, 104-105$

${ }^{33} \mathrm{lbid}, 106$.
} 


\section{Simpulan}

Badan hukum atau korporasi dapat dipertanggungjawabkan secara pidana harus dikaitkan dengan strict liability. Dimaksudkan dengan strict liability adalah pertanggungjawaban tanpa kesalahan (liability without fault), yang dalam hal ini pembuat sudah dapat dipidana jika telah melakukan perbuatan yang dilarang sebagaimana telah dirumuskan dalam undang-undang tanpa melihat lebih jauh sikap batin pelaku. Dalam hal ini cukup fakta yang berbicara, dan pelaku harus bertanggungjawab mutlak atas perbuatannya yang telah jelas mengakibatkan kerugian yang besar.

Sejalan dengan prinsip strict liability dalam UU No 32 Tahun 2009 tentang Perlindungan dan Pengelolaan Lingkungan Hidup, dalam hukum Islam dikenal dengan asas tersalah yakni ketidakhati-hatian dan ketidakwaspadaan. Setiap perbuatan tersalah tidak dijatuhi hukuman karena, ketersalahan telah menghapuskan salah satu unsur pidana, yaitu unsur kesengajaan. Hanya saja terhapusnya pertanggungjawaban pidana karena tidak adanya salah satu unsur asasi pidana, tidak menghalangi pertanggungjawaban secara perdata karena kaidah hukum Islam menetapkan bahwa darah dan harta benda dilindungi dan mendapat jaminan keselamatan (ma'sûm) dan alasan-alasan shar'i tidak bertentangan (tidak menghapuskan) jaminan keselamatan tersebut. Dan dalam asas tersalah ini tidak terdapat pembatasan ganti kerugian dalam kata lain, si pelaku wajib membayar ganti kerugian kepada korban secara utuh.

\section{Daftar Rujukan}

Hanafi, A. Asas-Asas Hukum Pidana Islam. Cet-3. Jakarta: Bulan Bintang, 1990.

Husin, Sukanda. Penegakan Hukum Lingkungan Indonesia. Jakarta: Sinar Grafika, 2009.

Koesoemahatmadja, Etty Utju R. Hukum Korporasi (Penegakan Hukum Terhadap Pelaku Economic Crimes dan Perlindungan Abuse of Power). Bogor: Ghalia Indonesia, 2011.

Machmud, Syahrul. Penegakan Hukum Lingkungan di Indonesia. Yogyakarta: Graha Ilmu, 2012.

Muladi, dan Dwidja Priyatno. Pertanggungjawaban Pidana Korporasi. Jakarta: Kencana, 2010. 
Muladi. Pertanggungjawaban Korporasi dalam Hukum Pidana. Bandung: Sekolah Tinggi Hukum Bandung, 1991.

Sherief Maronie, http://zriefmaronie.blogspot.com/2012/12/subjekhukum-pidana.html, 7 Des 2012

Siahaan, N.H.T. Hukum Lingkungan dan Ekologi Pembangunan. Jakarta: Erlangga, 2004.

Sianturi. Asas-asas Hukum Pidana di Indonesia dan Penerapannya. Jakarta: Story Grafika, 2002.

Tim Tsalisah. Ensiklopedi Hukum Pidana Islam. Bogor: Kharisma Ilmu.

UU RI No.32 Tahun 2009 Tentang Perlindungan dan Pengelolaan Lingkungan Hidup Lembaran Negara Republik Indonesia Tahun 2009 Nomor 140. 